\title{
Effect of Hippophae rhamnoides Extract on Oxidative Oropharyngeal Mucosal Damage Induced in Rats Using Methotrexate
}

\author{
Ertugrul Erhan ${ }^{1} \cdot$ Suat Terzi $^{2} \cdot$ Metin Celiker $^{3} \cdot$ Oguzhan Yarali $^{4} \cdot$ Murat Cankaya $^{5} \cdot$ Ferda Keskin Cimen $^{6} \cdot$ Ismail Malkoc $^{7}$ \\ Bahadir Suleyman ${ }^{8}$ \\ ${ }^{1}$ Department of Otorhinolaryngology, Faculty of Medicine, Erzincan University, Erzincan; ${ }^{2}$ Department of Otorhinolaryngology, Faculty of \\ Medicine, Recep Tayyip Erdogan University, Rize; ${ }^{3}$ Department of Otorhinolaryngology, Rize Education and Research Hospital, Rize; \\ ${ }^{4}$ Department of Medical Genetics, Erzurum Training and Research Hospital, Erzurum; ${ }^{5}$ Department of Biology, Faculty of Arts and Sciences, \\ Erzincan University, Erzincan; ${ }^{6}$ Department of Pathology, Mengucek Gazi Education and Research Hospital, Erzincan; ${ }^{7}$ Department of Anatomy, \\ Faculty of Medicine, Ataturk University, Erzurum; ${ }^{8}$ Department of Pharmacology, Faculty of Medicine, Erzincan University, Erzincan, Turkey
}

Objectives. The objective of this study is to investigate and evaluate the effect of Hippophae rhamnoides extract (HRE) on oropharyngeal mucositis induced in rats with methotrexate (MTX) through biochemical, gene expression, and histopathological examinations.

Methods. Experimental animals were divided into a healthy group (HG), a HRE+MTX (HREM) group, HRE group (HREG), and a control group that received MTX (MTXG). The HREM and HREG groups of rats was administered 50 $\mathrm{mg} / \mathrm{kg}$ HRE, while the MTXG and HG groups were given an equal volume distilled water with gavage. Then, the HREM and MTXG rat groups were given oral MTX at a dose of $5 \mathrm{mg} / \mathrm{kg} 1$ hour after HRE and distilled water was administered. This procedure was repeated for 1 month. At the end of this period, all of the animals were sacrificed with a high dose of anesthesia. Then, the amounts of malondialdehyde (MDA) and total glutathione (tGSH) were determined in the removed oropharyngeal tissues. Interleukin-1 $\beta$ (IL-1 $\beta)$ and tumor necrosis factor- $\alpha$ (TNF- $\alpha$ ) gene expressions were measured, and all the tissues were studied histopathologically.

Results. The amount of MDA was significantly increased in the MTXG group compared to the HREM, HREG, and HG groups $(P<0.001)$. MTX significantly decreased the amount of tGSH in the MTXG group compared to the HREM, HREG, and HG groups $(P<0.001)$. In this study, there were no visible ulcers in the animal group in which the levels of MDA, IL-1 $\beta$, and TNF- $\alpha$ were high and the level of tGSH was low. However, histopathologic examination revealed mucin pools in wide areas due to ruptured oropharynx glands, and proliferated, dilated, and congested blood vessels and dilated ductal structures in some areas.

Conclusion. HRE protected oropharyngeal oxidative damage induced by MTX. As an inexpensive and natural product, HRE has important advantages in the prevention of oropharyngeal damage induced by MTX.

Keywords. Methotrexate; Gene Expression; Hippophae; Rhamnoides; Oral Mucositis; Rat

\section{INTRODUCTION}

- Received February 8, 2016

Revised May 8, 2016

Accepted May 24, 2016

- Corresponding author: Ertugrul Erhan

Department of Otorhinolaryngology, Faculty of Medicine, Erzincan

University, 24030, Erzincan, Turkey

Tel: +90-505-210-4088, Fax: +90-446-226-1819

E-mail: dreerhan@hotmail.com
Oropharyngeal mucosal damage (mucositis) is a pathological condition seen during chemotherapy, causing discontinuation of treatment [1]. This event occurs as a result of epithelial cells damage during chemotherapy [2]. Mucositis begins with an inflammatory reaction, continues with ulcer formation, and results in infection in the aggravated state [3]. Excessive production of

Copyright (C) 2017 by Korean Society of Otorhinolaryngology-Head and Neck Surgery.

This is an open-access article distributed under the terms of the Creative Commons Attribution Non-Commercial License (http://creativecommons.org/licenses/by-nc/4.0)

which permits unrestricted non-commercial use, distribution, and reproduction in any medium, provided the original work is properly cited. 
proinflammatory cytokines, such as interleukin-1 $(\mathrm{IL}-1 \beta)$ and tumor necrosis factor- $\alpha$ (TNF- $\alpha$ ) is considered responsible for the inflammatory phase of mucositis [4]. A previous study reported that IL-1 $\beta$ and TNF- $\alpha$ are induced in mucositis related to chemotherapy [5]. Furthermore, the amount of malondialdehyde (MDA), which is an oxidant parameter, has been found to be increased, and the level of total glutathione (tGSH), which is an endogenous antioxidant, has been found to be decreased in mucositis; it has been reported that this is associated with oxidative stress and inflammation [6,7] of oropharyngeal mucositis. Moreover, tramadol, morphine, transdermal fentanyl, and buprenorphine are used [8]. However, although many studies have been conducted on the treatment of mucositis, an optimal approach is yet to be found. Therefore, oropharyngeal mucositis is considered as the most important complication resulting in the discontinuation of chemotherapy [9].

Methotrexate (MTX) is one of the most common causative agents in development of mucositis [10]. This is a folic acid antagonist antineoplastic drug used in the treatment of various cancer types. MTX is used at high doses for the treatment of malignancies [11]. However, high doses of MTX lead to the occurrence of severe adverse effects [12]. MTX and some antineoplastic drugs destruct the proliferating basal epithelial cells in the mucosal layer, thereby causing damage to the oral tissues [13]. Moreover, MTX has been reported to decrease the levels of tGSH and significantly increase the levels of MDA, IL-1 $\beta$, and TNF- $\alpha$ in the mucosa $[14,15]$. This information suggests that natural products featuring anti-inflammatory, antioxidant, antiulcer, and antimicrobial properties may be helpful in combatting the oropharyngeal toxicity of MTX.

Hippophae rhamnoides extract (HRE) from fruit, which we will test against oropharyngeal mucositis here, has been proven to be an antioxidant, antiulcerogenic, anti-inflammatory, antimicrobial, and proinflammatory cytokine antagonist [16-18]. The H. rhamnoides L. plant, which is a member of Elaeagnaceae family, contains carotenoids $(\alpha, \beta, \gamma)$, riboflavin, vitamin $C$, tocopherol, tocotrienol, folic acid, tannin, and fatty acids $[17,18]$. No studies were found in the literature that evaluated the protective effect of HRE against oropharyngeal mucositis induced by MTX. Therefore, the objective of this study is to investigate and evaluate the effect of HRE on oropharyngeal mucositis induced in rats with MTX through biochemical, gene expression,

\section{H I}

- Ettect of Hippophae rhammoides extract (HRE) on oropharyngeal mucositis was examined.

- Biochemical and histological examinations revealed less injury in the HRE group compared to control.

- HRE protected oropharyngeal oxidative damage induced by methotrexate. and histopathological examinations.

\section{MATERIALS AND METHODS}

\section{Animals}

Experimental animals were obtained from Ataturk University's Medical Experimental Application and Research Center. A total of 40 Wistar albino male rats weighing 220-235 g were used in the experiment. Before initiation of the experiment, animals were housed and fed in groups ( $\mathrm{n}=10$ in each) in the pharmacology laboratory at normal room temperature $\left(22^{\circ} \mathrm{C}\right)$. The study was conducted in Ataturk University Experimental Studies and Research Center, Erzurum. The experimental procedure was approved by the Committee for Animal Research of Ataturk University, Erzurum. This study was carried out in accordance with international guidelines on the ethical use of animals (Ethics Committee no.: 29.01.2016/24).

\section{Chemical agents}

The chemical agents used in the experiment were as follows: MTX from Med-Ilac, Istanbul, Turkey; thiopental sodium from I. E. Ulagay, Istanbul, Turkey; and HRE from Karen Bilim, Turkey.

\section{Experimental procedures}

Experimental animals were divided into the following groups: a healthy group (HG), an HRE+MTX (HREM) group, HRE group (HREG), and a control group that received MTX (MTXG). The HREM and HREG groups of rats $(\mathrm{n}=10)$ was administered 50 $\mathrm{mg} / \mathrm{kg}$ HRE, while the MTXG $(\mathrm{n}=10)$ and HG $(\mathrm{n}=10)$ groups were given an equal volume of distilled water with gavage. Then HREM and MTXG rat groups were given oral MTX at a dose of $5 \mathrm{mg} / \mathrm{kg} 1$ hour after HRE and distilled water was administered. This procedure was repeated for 1 month. At the end of this period, all the animals were sacrificed with a high dose of anesthesia after measuring the weight of all animals. Then, the amounts of MDA and tGSH were determined in the removed oropharyngeal tissues. In addition, IL- $1 \beta$ and TNF- $\alpha$ gene expressions were measured, and all the tissues were histopathologically studied.

\section{Biochemical analyses \\ MDA analysis}

According to the method defined by Ohkawa et al. [19], MDA forms a pink complex with thiobarbi-turic acid (TBA) at $95^{\circ} \mathrm{C}$, which can be measured using spectrophotometry at a wavelength of $532 \mathrm{~nm}$. In the experiment, $0.1 \mathrm{~mL}$ of homogenate was added to a solution containing $0.1 \mathrm{~mL}$ of $8.1 \%$ sodium dodecyl sulfate (SDS), $1.5 \mathrm{~mL}$ of $20 \%$ acetic acid (Merck, Darmstadt, Germany), $1.5 \mathrm{~mL}$ of $0.9 \%$ TBA (Sigma-Aldrich, Schnelldorf, Germany), and $0.3 \mathrm{~mL}$ of DH2O. The mixture was incubated at $95^{\circ} \mathrm{C}$ for 1 hour. Upon cooling, $5 \mathrm{~mL}$ of n-butanol: pyridine (v/v, 15:1; Merck) was added. The mixture was vortexed 
for 1 minute and centrifuged for 30 minutes at 4,000 rpm. The absorbance of the $0.15 \mathrm{~mL}$ supernatant was measured at 532 $\mathrm{nm}$ by spectrophotometry. The standard curve was obtained using 1,1,3,3-tetramethoxypropane (Sigma-Aldrich).

\section{tGSH analysis}

According to the method defined by Sedlak and Lindsay [20] 5,5'-dithiobis (2-nitrobenzoic acid) (DTNB) disulfite is chromogenic in the medium, and DTNB is reduced easily by sulfhydryl groups. The yellow color produced during the reduction is measured by spectrophotometry at $412 \mathrm{~nm}$. For measurement, a cocktail solution $(5.85 \mathrm{~mL}$ of $100 \mathrm{mM} \mathrm{Na}$ phosphate buffer, 2.8 $\mathrm{mL}$ of $1 \mathrm{mM}$ DTNB [Sigma-Aldrich], $3.75 \mathrm{~mL}$ of $1 \mathrm{mM}$ nicotinamide adenine dinucleotide phosphate [NADPH; Sigma-Aldrich], and $80 \mu \mathrm{L}$ of $625 \mathrm{U} / \mathrm{L}$ glutathione reductase [Sigma-Aldrich]) was prepared. Before measurement, $0.1 \mathrm{~mL}$ of metaphosphoric acid (Sigma-Aldrich) was added onto $0.1 \mathrm{~mL}$ of homogenate and centrifuged for 2 minutes at 2,000 rpm for deproteinization. A $0.15-\mathrm{mL}$ cocktail solution was added onto $50 \mu \mathrm{L}$ of supernatant. The standard curve was obtained by using GSSG (Sigma-Aldrich).

\section{Gene expression of IL-1 $\beta$ and TNF- $\alpha$}

RNA isolation: RNA was isolated from the homogenized oral tissue samples using a Roche Magna Pure Compact LC device (Roche Diagnostics, Mannheim, Germany) with a MagNAMagNA Pure LC RNA Kit (Roche Diagnostics). The quantity and quality of the isolated RNA was assessed with a nucleic acid measurement device (MaestroNano, Las Vegas, NV, USA). Then, $50 \mu \mathrm{L}$ of RNA samples was stored at $-80^{\circ} \mathrm{C}$.

cDNA synthesis: cDNA was synthesized from the isolated RNA samples using the Transcriptor First Strand cDNA synthesis kit (Roche Diagnostics). For each subject, $1 \mu \mathrm{L}$ of ddH2O, 10 $\mu \mathrm{L}$ RNA, and $2 \mu \mathrm{L}$ of Random Primer were combined and incubated in a Thermal Cycler for 10 minutes at $65^{\circ} \mathrm{C}$. After incubation, $4 \mu \mathrm{L}$ of reaction buffer, $0.5 \mu \mathrm{L}$ of RNAase, $2 \mu \mathrm{L}$ of Deoxynucleotide Mix, and $0.5 \mu \mathrm{L}$ of reverse transcriptase were added, and the reactions were incubated at 10 minutes at $25^{\circ} \mathrm{C}, 30$ minutes at $55^{\circ} \mathrm{C}$, and 5 minutes at $85^{\circ} \mathrm{C}$, then held at $4^{\circ} \mathrm{C}$.

Quantitative gene expression evaluation by real-time quantitative polymerase chain reaction (RT-qPCR): For each cDNA sample, gene expression of myeloperoxidase (MPO) and the reference gene (G6PD) was analyzed using the Roche Light Cycler 480 II Real-Time PCR instrument (Roche Diagnostics). Polymerase chain reaction (PCR) reactions were carried out in a final volume of $20 \mu \mathrm{L}$ with the following ingredients: $5 \mu \mathrm{L}$ of cDNA, $3 \mu \mathrm{L}$ of distilled water, $10 \mu \mathrm{L}$ of Light Cycler 480 Probes Master (Roche Diagnostics), and $2 \mu \mathrm{L}$ of primer-probe set (RealTime Ready single assay, Roche Diagnostics). Cycle conditions of the relative quantitative PCR (qPCR) were as follows: preincubation at $95^{\circ} \mathrm{C}$ for 10 minutes, followed by 45 amplification cycles of $95^{\circ} \mathrm{C}$ for 10 seconds, $6^{\circ} \mathrm{C}$ for 30 seconds, and $72^{\circ} \mathrm{C}$ for
1 second, followed by cooling at $40^{\circ} \mathrm{C}$ for 30 seconds. qPCR analysis and calculation of quantification cycle $(\mathrm{Cq})$ values for relative quantification were performed using the Light Cycler 480 Software, ver. 1.5 (Roche Diagnostics). Relative quantitative amounts were calculated by dividing the target genes by the expression level of the reference gene. The reference gene was used for the normalization of target gene expression.

\section{Histopathological examination}

The oropharyngeal tissues removed from the rats were fixed in $10 \%$ formalin solution for 24 hours. Following routine tissue processing, paraffin blocks were cut into $4 \mu \mathrm{m}$ thick sections, which were then stained with hematoxylin and eosin (H\&E). All of the sections were evaluated by a pathologist who was blinded to the treatment protocols using an optic microscope (Olympus BX 52, Olympus, Tokyo, Japan).

\section{Statistical analysis}

Statistical analyses were carried out using the IBM SPSS ver. 22.0 (IBM Co., Armonk, NY, USA). Descriptive statistics for each variable were determined. The significance of differences between the groups was determined using the one-way analysis of variance (ANOVA) test followed by Fisher post hoc least significant differences (LSD) analysis. A $P$-value less than 0.05 was considered significant.

\section{RESULTS}

\section{The weight animal}

Pre-experiment weights of animals in MTXG, HREM, HREG, and HG groups were found as $232 \pm 3.5 \mathrm{~g}, 229 \pm 3.8 \mathrm{~g}, 225 \pm 3.3$ $\mathrm{g}$, and $227 \pm 3.3 \mathrm{~g}$, respectively. However, at the end of the experiment the weight of animals in MTXG dropped to $221 \pm 3.8$ $\mathrm{g}$, while weight of animals in HREM, HREG, and HG groups raised to $241 \pm 4.2 \mathrm{~g}, 247 \pm 4.5 \mathrm{~g}$, and $243 \pm 4.6 \mathrm{~g}$, respectively. This indicates that, the mean weight of animals in MTXG group was decreased by $11 \mathrm{~g}$ and the mean weights of animals in HREM, HREG, and HG groups were increased by 12,22 , and $16 \mathrm{~g}$, respectively.

\section{Biochemical results}

As seen in Fig. 1, the amount of MDA was $9.1 \pm 0.8 \mathrm{nmol} / \mathrm{mL}$ in oropharyngeal tissues of the animals administered MTX, while the MDA amounts were similar in the HREM and HREG groups $(2.6 \pm 0.6 \mathrm{nmol} / \mathrm{mL}$ and $2.1 \pm 0.3 \mathrm{nmol} / \mathrm{mL})$ and healthy $(2.8 \pm$ $0.3 \mathrm{nmol} / \mathrm{mL}$ ) groups. The amount of MDA was significantly increased in the MTXG rat group compared to the HREM, HREG, and HG groups $(P<0.001)$. MTX significantly decreased the amount of tGSH in the MTXG group $(1.6 \pm 0.3 \mathrm{mg} / \mathrm{L})$ compared to the HREM, HREG, and HG groups $(P<0.001)$, while the amount of tGSH was found to be significantly higher in the 


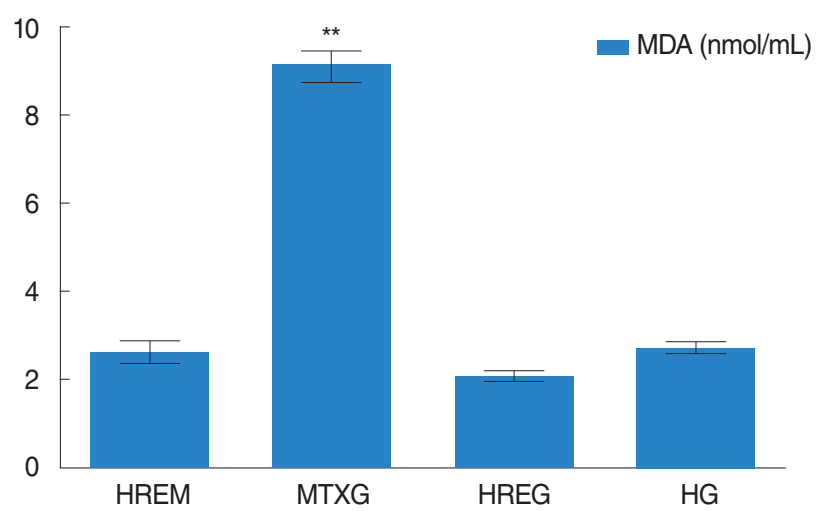

Fig. 1. The effects of Hippophae rhamnoides extract (HRE) on malondialdehyde (MDA) levels. HREM, HRE+methotrexate (MTX); MTXG, control group that received MTX; HREG, HRE group; HG, healthy group. ${ }^{*} P<0.001$.

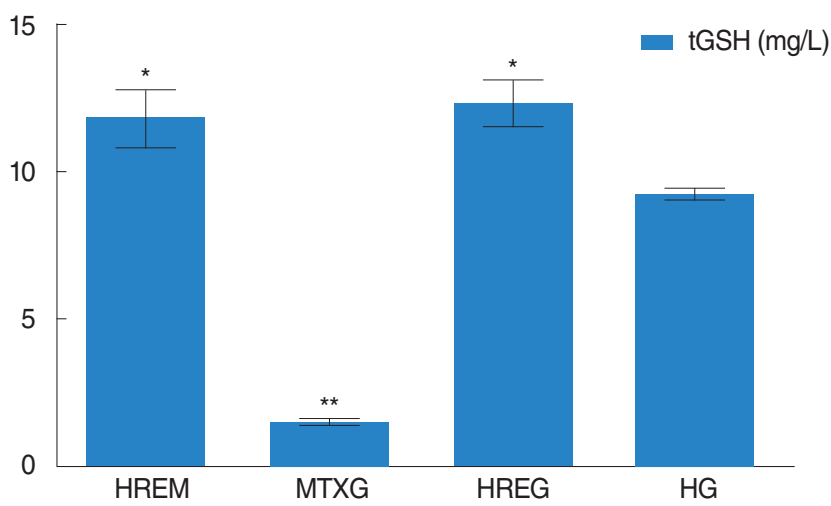

Fig. 2. The effects of Hippophae rhamnoides extract (HRE) on total glutathione (tGSH) levels. HREM, HRE+methotrexate (MTX); MTXG, control group that received MTX; HREG, HRE group; HG, healthy group. ${ }^{\star} P<0.01$. ${ }^{\star \star} P<0.001$.

HREM group $(11.8 \pm 2.3 \mathrm{mg} / \mathrm{L}, 12.3 \pm 1.9 \mathrm{mg} / \mathrm{L})$ compared to the HG group (9.2 $\pm 0.5 \mathrm{mg} / \mathrm{L} ; P<0.01)$ (Fig. 2).

\section{Gene expression results}

MTX raised IL-1 $\beta$ gene expression to $7.0 \pm 1.0$ in the oropharyngeal tissue of the MTXG group, while these values were found to be $2.6 \pm 0.2,1.9 \pm 0.4$, and $2.2 \pm 0.2$ in the HREM, HREG, and HG groups, respectively. IL-1 $\beta$ gene expression in the MTXG group was found to be significantly increased $(P<0.001)$ compared to the HREM, HREG, and HG groups (Fig. 3). TNF- $\alpha$ gene expression value was found as $5.7 \pm 0.9$ in the MTXG group, $2.2 \pm 0.2$ in the HREM group, $1.8 \pm 0.8$ in the HREG and $2.1 \pm 0.3$ in the HG group. Statistical analysis shows that TNF- $\alpha$ gene expression was significantly raised in MTX $(P<0.001)$ compared to HREM, HREG, and HG (Fig. 3).

\section{Histopathological results}

Fig. 4 illustrates the normal histopathological appearance of the

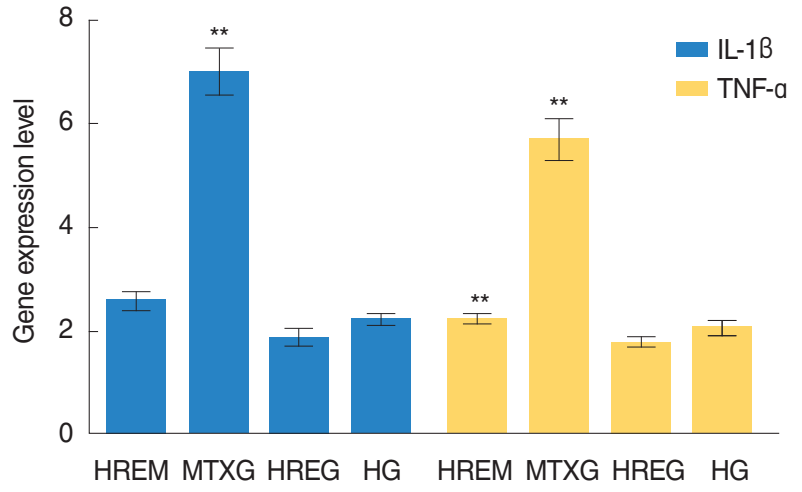

Fig. 3. The effects of Hippophae rhamnoides extract (HRE) on Interleukin-1B (IL-1B) and tumor necrosis factor (TNF-a) gene expression level. HREM, HRE+methotrexate (MTX); MTXG, control group that received MTX; HREG, HRE group; HG, healthy group. ${ }^{* \star} P<0.001$.

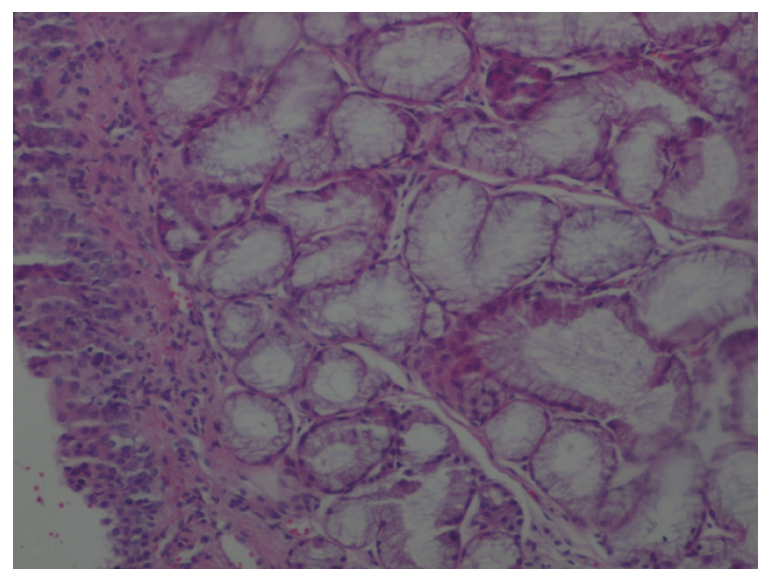

Fig. 4. Normal histopathological appearance of the healthy group oropharyngeal tissue $(\mathrm{H \& E}, \times 40)$.

oropharyngeal tissue in the HG group. However, there were mucin pools in wide areas (star) in the group administered MTX (Fig. 5A), and proliferated, dilated, and congested blood vessels were observed in some areas (Fig. 5B). Again, dilated ductal structures were observed in the oropharyngeal tissue of the MTXG group (Fig. 5C). Additionally, an inflamed area containing marked polymorphonuclear leukocytes (PNL) infiltration was found in the oropharynx which was treated with MTX (Fig. 5D). The oropharyngeal tissue of the rats treated with HRE resembled healthy tissue (Fig. 6). No pathological findings were found in the oropharyngeal tissue of HREG animals administered HRE alone (Fig. 7).

\section{DISCUSSION}

Oropharyngeal mucositis is a critical complication causing discontinuation of chemotherapy, negatively affecting quality of 

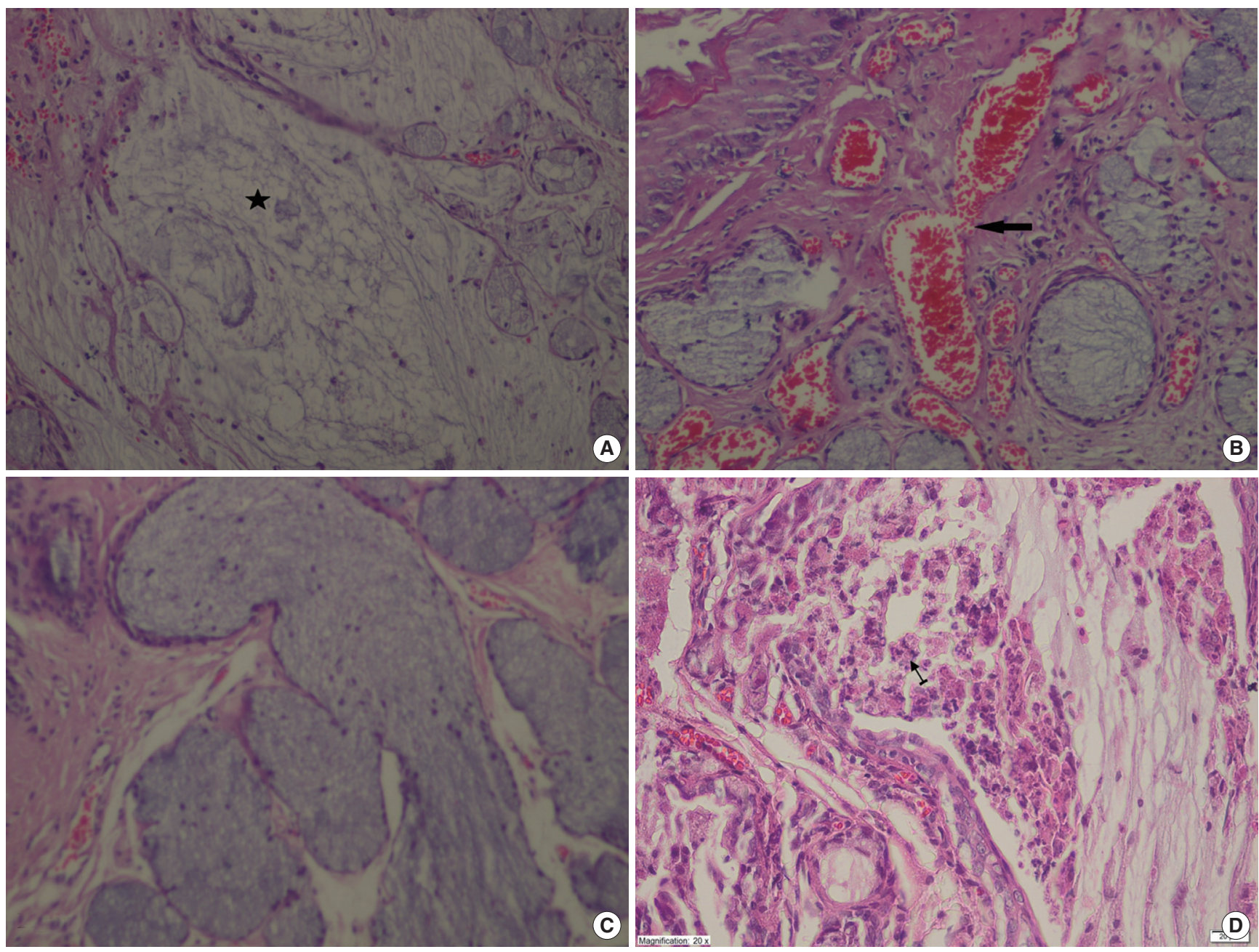

Fig. 5. (A) Mucin pools in wide areas (star) due to the ruptured gland in the oropharyngeal tissue of the control group that received methotrexate (MTXG) (H\&E, X100). (B) Proliferated, dilated, and congested blood vessels (arrow) in the oropharyngeal tissue of the MTXG group (H\&E, $\times 100)$. (C) Dilated ductal structures in the oropharyngeal tissue of the MTXG group (H\&E, $\times 100)$. (D) Inflamed area (arrow) containing significant polymorphonuclear leukocytes in the oropharyngeal tissue of MTXG group (H\&E, $\times 40)$.

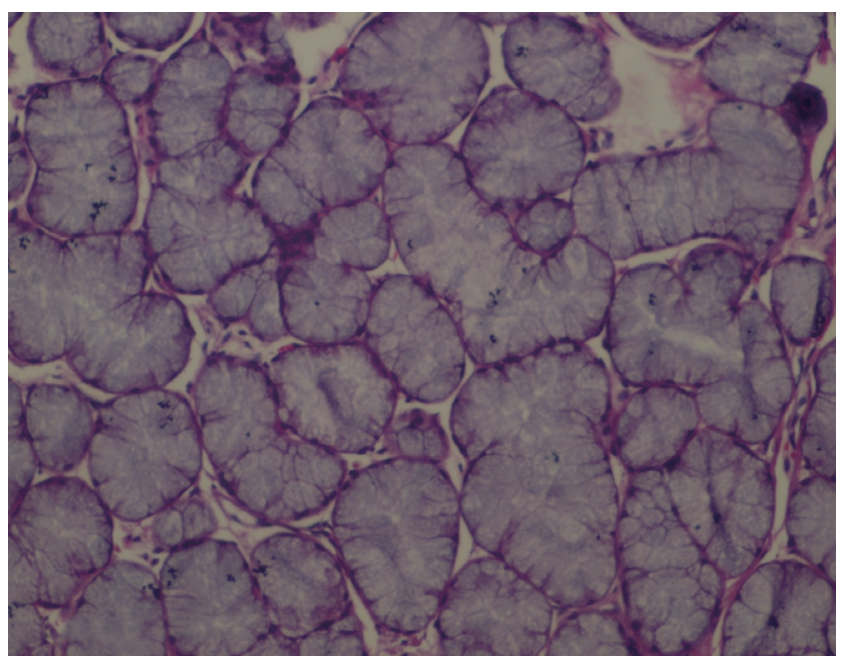

Fig. 6. Appearance of Hippophae rhamnoides extract+methotrexate oropharyngeal tissue resembling healthy tissue $(\mathrm{H} \& \mathrm{E}, \times 40)$.

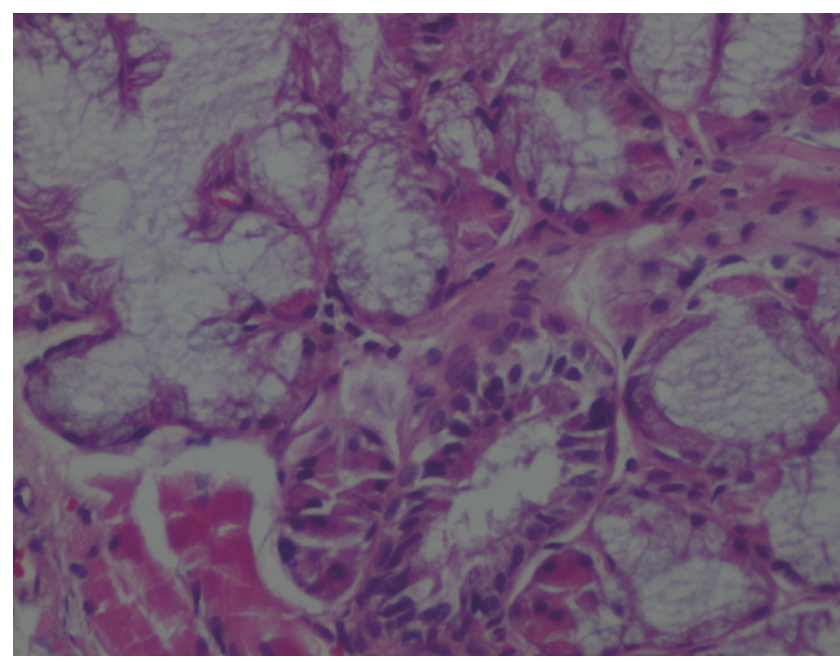

Fig. 7. Normal histopathologic appearance of the oropharyngeal tissue of Hippophae rhamnoides extract group (H\&E, X40). 
life, and increasing the cost of care [9]. In the present study, the effect of HRE on oropharyngeal mucositis induced in rats with MTX was investigated and evaluated through biochemical, gene expression, and histopathological examinations. The biochemical results of the experiment indicated that the amount of MDA was increased and the amount of tGSH was decreased in the rats administered MTX compared to the HREM, HREG, and HG groups. MDA is known to be an oxidant and GSH is an antioxidant agent [21]. It was seen in our experimental results that oxidant/antioxidant balance changed in favor of oxidants in the oropharyngeal tissue of the animals administered MTX. Meanwhile, this balance was maintained with the superiority of antioxidants in physiological conditions [22]. The change of this balance in favor of oxidants leads to tissue damage that is termed oxidative stress [23]. This indicates that oxidant/antioxidant balance is an important indicator in evaluating whether tissue damage has occurred [24]. No information was found in the literature to suggest that MTX increases MDA and decreases tGSH in the oropharyngeal tissue. However, the role of reactive oxygen species has been shown in the etiopathogenesis of mucositis related to MTX [12]. MTX causes a decrease in intracellular NADPH by inhibiting cytosolic nicotinamide adenine phosphate dehydrogenase (NADPDH) and NADP-dependent malic enzyme; NADPH is required for the glutathione reductase (GSSGR) enzyme, which provides continuity of reduced glutathione-a cytosolic antioxidant. Therefore, MTX therapy results in decreased effectiveness of the antioxidant defense system that protects the cells against reactive oxygen radicals [25]. Recent studies have underlined that MTX increases the amount of MDA and decreases the amount of tGSH in the intestinal mucosal tissue [26]. Information obtained from the literature and our experimental results indicates that oxidative stress developed in the oropharyngeal tissue of the animals given MTX.

In the current study, we found significant increases in IL-1 $\beta$ and TNF- $\alpha$ gene expression in the MTXG group, in which MDA was increased and tGSH was decreased. Logan and colleagues demonstrated that IL-1 $\beta$ and TNF- $\alpha$ are increased in mucositis related to MTX and other chemotherapy medications [27]. de Araujo et al. [28] stated that inflammation was developed in an MTX mucositis model where proinflammatory cytokines, such as IL- $1 \beta$ and TNF- $\alpha$, were implicated. This information suggests that inflammation and oxidative stress developed due to MTX in the oropharyngeal tissue in our study. The levels of both oxidants and proinflammatory cytokines, such as IL-1 $\beta$ and TNF- $\alpha$, were found to be significantly lower in the oropharyngeal tissue of the rats treated with HRE than in the animals administered MTX. The protection of oropharyngeal tissue by HRE against MTX might be have resulted from the antioxidant, anti-ulcerogenic, anti-inflammatory, antimicrobial, and proinflammatory cytokine antagonist characteristics of HRE, as mentioned above $[16,18]$. As is known, $H$. rhamnoides fruit contains different rates of carotenes $\alpha, \beta$, and $\gamma$. $\beta$-Carotene has been proven to have protective effect against the development of mucositis in cancer patients receiving chemotherapy [29]. HRE has been reported to protect gastric tissue against oxidative damage via MTX by preventing the increase of MDA and decrease of tGSH in the gastric tissue [30]. H. rhamnoides fruits have been reported to contain carotenes, fatty acids, and many water- and fatsoluble vitamins that have antioxidant, anti-inflammatory, and antiulcer IL-1 $\beta$ and TNF- $\alpha$ antagonist features [31].

In this study, there were no visible ulcers in the animal group in which the levels of MDA, IL-1 $\beta$, and TNF- $\alpha$ were high and the level of tGSH was low. However, histopathological examination revealed mucin pools in wide areas due to ruptured oropharynx glands, and proliferated, dilated, and congested blood vessels, dilated ductal structures and marked inflammation accompanying by the infiltration of PNL in some areas. The low levels of MDA, IL-1 $\beta$, and TNF- $\alpha$ and the high level of tGSH in the oropharyngeal tissue of the animals treated with HRE were consistent with the histopathological findings.

In conclusion, MTX produced oxidative stress in the oropharyngeal tissue, while HRE prevented oropharyngeal oxidative damage induced by MTX. None of the pathological findings observed in the oropharyngeal tissue of the animals in MTXG were found in the rats in the HREM group. As an inexpensive and natural product, HRE has important advantages in the prevention of oropharyngeal damage induced by MTX.

\section{CONFLICT OF INTEREST}

No potential conflict of interest relevant to this article was reported.

\section{REFERENCES}

1. Kwong KK. Prevention and treatment of oropharyngeal mucositis following cancer therapy: are there new approaches? Cancer Nurs. 2004 May-Jun;27(3):183-205.

2. Weisdorf DJ, Bostrom B, Raether D, Mattingly M, Walker P, Pihlstrom B, et al. Oropharyngeal mucositis complicating bone marrow transplantation: prognostic factors and the effect of chlorhexidine mouth rinse. Bone Marrow Transplant. 1989 Jan;4(1):89-95.

3. Sonis ST. Mucositis: the impact, biology and therapeutic opportunities of oral mucositis. Oral Oncol. 2009 Dec;45(12):1015-20.

4. Scully C, Epstein J, Sonis S. Oral mucositis: a challenging complication of radiotherapy, chemotherapy, and radiochemotherapy: part 1, pathogenesis and prophylaxis of mucositis. Head Neck. 2003 Dec; 25(12):1057-70.

5. Ahmed KM. The effect of olive leaf extract in decreasing the expression of two pro-inflammatory cytokines in patients receiving chemotherapy for cancer: a randomized clinical trial. Saudi Dent J. 2013 Oct;25(4):141-7.

6. Mardani M, Afra SM, Tanideh N, Tadbir AA, Modarresi F, KoohiHosseinabadi O, et al. Hydroalcoholic extract of Carum carvi L. in oral mucositis: a clinical trial in male golden hamsters. Oral Dis. 
2016 Jan;22(1):39-45.

7. de Araujo RF Jr, Reinaldo MP, Brito GA, Cavalcanti Pde F, Freire MA, de Medeiros CA, et al. Olmesartan decreased levels of IL-1 $\beta$ and TNF- $\alpha$, down-regulated MMP-2, MMP-9, COX-2, RANK/ RANKL and up-regulated SOCs-1 in an intestinal mucositis model. PLoS One. 2014 Dec;9(12):e114923.

8. Vokurka S. Oropharyngeal mucositis: pain management. Klin Onkol. 2011;24(4):278-80.

9. Epstein JB, Tsang AH, Warkentin D, Ship JA. The role of salivary function in modulating chemotherapy-induced oropharyngeal mucositis: a review of the literature. Oral Surg Oral Med Oral Pathol Oral Radiol Endod. 2002 Jul;94(1):39-44.

10. Brown CG, Yoder LH. Stomatitis: an overview: protecting the oral cavity during cancer treatment. Am J Nurs. 2002 Apr;102 Suppl 4: 20-3.

11. Altindag O, Kucukoglu B. Intoxication due to high dose methotrexate in a patient with rheumatoid arthritis: a case report. Turk J Rheumatol. 2011;26(1):58-60.

12. Vanhoecke B, Bateman E, Mayo B, Vanlancker E, Stringer A, Thorpe D, et al. Dark Agouti rat model of chemotherapy-induced mucositis: establishment and current state of the art. Exp Biol Med (Maywood). 2015 Jun;240(6):725-41.

13. Ilgenli T, Oren H, Uysal K. The acute effects of chemotherapy upon the oral cavity: prevention and management. Turk J Cancer. 2001 Jul;31(3):93-105.

14. Jahovic N, Sener G, Cevik H, Ersoy Y, Arbak S, Yegen BC. Amelioration of methotrexate-induced enteritis by melatonin in rats. Cell Biochem Funct. 2004 May-Jun;22(3):169-78.

15. Alamir I, Boukhettala N, Aziz M, Breuille D, Dechelotte P, Coeffier M. Beneficial effects of cathepsin inhibition to prevent chemotherapy-induced intestinal mucositis. Clin Exp Immunol. 2010 Nov;162 (2):298-305.

16. Suleyman H, Demirezer LO, Buyukokuroglu ME, Akcay MF, Gepdiremen A, Banoglu ZN, et al. Antiulcerogenic effect of Hippophae rhamnoides L. Phytother Res. 2001 Nov;15(7):625-7.

17. Andersson SC, Rumpunen K, Johansson E, Olsson ME. Tocopherols and tocotrienols in sea buckthorn (Hippophae rhamnoides L.) berries during ripening. J Agric Food Chem. 2008 Aug;56(15):6701-6.

18. Kwon DJ, Bae YS, Ju SM, Goh AR, Choi SY, Park J. Casuarinin suppresses TNF- $\alpha$-induced ICAM- 1 expression via blockade of NF- $\mathrm{KB}$ activation in HaCaT cells. Biochem Biophys Res Commun. 2011 Jun;409(4):780-5.

19. Ohkawa H, Ohishi N, Yagi K. Assay for lipid peroxides in animal tissues by thiobarbituric acid reaction. Anal Biochem. 1979 Jun;95(2):
351-8.

20. Sedlak J, Lindsay RH. Estimation of total, protein-bound, and nonprotein sulfhydryl groups in tissue with Ellman's reagent. Anal Biochem. 1968 Oct 24;25(1):192-205.

21. Kisaoglu A, Borekci B, Yapca OE, Bilen H, Suleyman H. Tissue damage and oxidant/antioxidant balance. Eurasian J Med. 2013 Feb;45 (1):47-9.

22. Clarkson PM,Thompson HS. Antioxidants: what role do they play in physical activity and health? Am J Clin Nutr. 2000 Aug;72(2 Suppl): 637S-46S.

23. Yeum KJ, Russell RM, Krinsky NI, Aldini G. Biomarkers of antioxidant capacity in the hydrophilic and lipophilic compartments of human plasma. Arch Biochem Biophys. 2004 Oct;430(1):97-103.

24. Aguilar A, Alvarez-Vijande R, Capdevila S, Alcoberro J, Alcaraz A. Antioxidant patterns (superoxide dismutase, glutathione reductase, and glutathione peroxidase) in kidneys from non-heart-beating-donors: experimental study. Transplant Proc. 2007 Jan-Feb;39(1):24952.

25. Cetinkaya A, Bulbuloglu E, Kurutas EB, Kantarceken B. N-acetylcysteine ameliorates methotrexate-induced oxidative liver damage in rats. Med Sci Monit. 2006 Aug;12(8):BR274-8.

26. Arslan A, Ozcicek F, Keskin Cimen F, Altuner D, Yarali O, Kurt N, et al. Protective effect of resveratrol against methotrexate-induced oxidative stress in the small intestinal tissues of rats. Int J Clin Exp Med. 2015 Jul;8(7):10491-500.

27. Logan RM, Stringer AM, Bowen JM, Gibson RJ, Sonis ST, Keefe DM. Is the pathobiology of chemotherapy-induced alimentary tract mucositis influenced by the type of mucotoxic drug administered? Cancer Chemother Pharmacol. 2009 Jan;63(2):239-51.

28. de Araujo AA, Borba PB, de Souza FH, Nogueira AC, Saldanha TS, Araujo TE, et al. In a methotrexate-induced model of intestinal mucositis, olmesartan reduced inflammation and induced enteropathy characterized by severe diarrhea, weight loss, and reduced sucrose activity. Biol Pharm Bull. 2015;38(5):746-52.

29. Mills EE. The modifying effect of beta-carotene on radiation and chemotherapy induced oral mucositis. Br J Cancer. 1988 Apr;57(4): 416-7.

30. Yilmaz I, Demiryilmaz I, Sener E, Cetin N, Ucuncu Y, Altuner D, et al.The effect of hippophae rhamnoides extract on oxidative damage on rat's gastric tissue depending on co-implementation of methotrexate and indomethacin. Lat Am J Pharm. 2014;33(3):453-8.

31. Suryakumar G, Gupta A. Medicinal and therapeutic potential of Sea buckthorn (Hippophae rhamnoides L.). J Ethnopharmacol. 2011 Nov;138(2):268-78. 